\title{
PERANCANGAN FONDASI GEDUNG TEMPORARY EVACUATION SHELTER (TES) TSUNAMI DAN GEMPA
}

\author{
Mitsaq Addina Nisa1, Iman Satyarno², Hary Christady Hardiyatmo1 \\ ${ }^{1,2,3}$ Departemen Teknik Sipil dan Lingkungan, Universitas Gadjah Mada, Yogyakarta, Indonesia. \\ Email: m.addinanisa@gmail.com
}

\begin{abstract}
ABSTRAK
Temporary Evacuation Shelter (TES) didefinisikan sebagai bangunan yang berfungsi untuk tempat tujuan evakuasi. TES disebut juga bangunan penyelamatan dan perlindungan vertikal. Selain fungsi utama TES sebagai tempat evakuasi saat terjadi bencana gempa maupun tsunami, TES diharapkan mempunyai fungsi sekunder, yaitu sebagai fasilitas umum seperti tempat rekreasi, sekolah, tempat ibadah, dan lain-lain. TES dengan konstruksi yang kuat diharapkan dapat menjadi alternatif mitigasi untuk menekan korban jiwa akibat bencana gempa dan tsunami. Untuk memastikan ketahanan dan kekuatan struktur TES, perlu dilakukan evaluasi struktur fondasi dengan memperhatikan kondisi tanah dan potensi-potensi kerusakan di sekitar lokasi, yaitu likuifaksi dan scouring. Kemudian dilakukan permodelan untuk mengetahui apakah fondasi yang direncanakan mampu menahan bebanbeban yang terjadi pada bangunan dan fondasi.
\end{abstract}

Kata kunci: Temporary Evacuation Shelter, vertical evacuation, fondasi, Plaxis 2D, SAP2000, Response 2000.

\section{ABSTRACT}

Temporary Evacuation Shelter (TES) is defined as a building used for evacuation facilities. It is also referred to as a vertical evacuation building. In addition to the main function of TES as an evacuation site during an earthquake or tsunami, TES also has a secondary function, namely as public facilities such as recreation areas, schools, places of worship, and others. A well-constructed TES is expected to be an alternative mitigation to reduce damage and casualties due to earthquakes and tsunamis. To ensure the durability and strength of the TES structure, it is necessary to evaluate the foundation structure by checking soil conditions and potential structural failures around the site, namely liquefaction and scouring. The TES substructure is modeled to see whether the design foundation can withstand the loads that occurred to the building and foundations.

Keywords: Temporary Evacuation Shelter, vertical evacuation, foundation, Plaxis 2D, SAP2000, Response 2000.

\section{PENDAHULUAN}

Indonesia terletak di daerah rawan gempa bumi karena dilalui oleh jalur pertemuan 3 lempeng utama dunia dan berada pada Pasific Ring of Fire merupakan jalur rangkaian gunung api aktif di dunia yang setiap saat dapat meletus dan mengakibatkan datangnya bencana. Hal itu menjadikan Indonesia wilayah dengan ancaman bencana gempa bumi dan tsunami dengan intensitas yang cukup tinggi.

Catatan Direktorat Vulkanologi dan Mitigasi Bencana Geologi (DVMBG) Departemen Energi dan Sumber Daya Mineral menunjukan bahwa ada 28 wilayah di Indonesia yang dinyatakan rawan gempa dan tsunami. Di antaranya Nanggroe Aceh Darussalam (NAD). Sumatra Utara, Sumatra Barat, Bengkulu, Lampung, Banten, Jateng dan DIY bagian selatan, Jatim bagian selatan, Bali, NTB dan NTT, kemudian Sulut, Sulteng, Sulsel, Maluku Utara, Maluku Selatan, Biak, Yapen dan Fak-Fak di Papua serta Balikpapan Kalimantan Timur.

Mitigasi sangat diperlukan sebagai tindakan atau upaya preventif untuk meminimalisasi dampak negatif kerusakan bencana baik di sisi korban jiwa maupun materiil. Mitigasi dapat bersifat struktural maupun nonstruktural. Mitigasi struktural berupa pembangunan infrastruktur yang menunjang sistem evakuasi masyarakat di 
kawasan rawan bencana, juga merupakan antisipasi di masa mendatang dan investasi jangka panjang bagi kesejahteraan masyarakat. Untuk mengurangi jumlah dan risiko tersebut, pemerintah Indonesia telah menyediakan Temporary Evacuation Shelter (TES) gempa dan tsunami di beberapa daerah seperti TES Aceh, TES Padang, TES Bengkulu, TES Banten, TES Bantul DIY, TES Bali dan TES Lombok. Bappenas (2005) menyebutkan bahwa bangunan Temporary Evacuation Shelter (TES) harus memiliki kinerja yang baik saat terjadi gempa dan tsunami maupun setelah peristiwa tersebut, terutama dalam struktur fondasinya di samping struktur atas bangunan.

\section{Tercatat terjadi beberapa kegagalan} struktur pada Temporary Evacuation Shelter (TES), salah satunya terjadi di TES Lombok Utara akibat gempa Lombok 2018 yang memperlihatkan kerusakan serius pada struktur seperti terlihat pada Gambar 1.

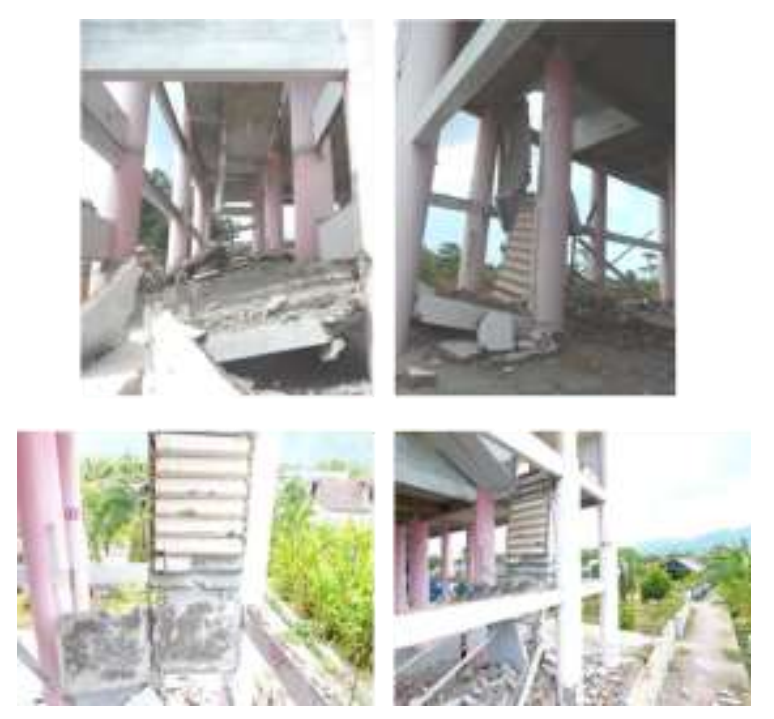

Gambar 1. Kerusakan TES Lombok Utara (Satyarno dkk., 2018)

Ketahanan suatu bangunan tergantung pada fondasi yang dirancang. Hal ini dikarenakan kegagalan tanah akan mengakibatkan kegagalan struktur secara keseluruhan. Fondasi merupakan elemen penting pada bangunan karena berfungsi untuk meneruskan beban dari struktur atas ke bagian tanah dasar dan menahan beban lateral dari tanah pada bangunan.

Sebelum merancang fondasi perlu dilakukan survei untuk mengidentifikasi struktur tanah. Pemilihan tipe fondasi yang akan digunakan ditinjau berdasarkan hasil dari uji SPT (Standard Penetration Test) pada lokasi pembangunan TES.

\section{Potensi Kerusakan di sekitar Fondasi}

Potensi terjadinya likuifaksi merupakan aspek penting yang harus diperhatikan sebelum mendesain fondasi. Mengacu pada peristiwa gempa Palu 2018 (Gambar 2), likuifaksi dapat menyebabkan kegagalan struktur.

Kegagalan fondasi TES memang belum teridentifikasi di Indonesia. Namun untuk menjamin keamanan dari struktur TES, potensi terjadinya likuifaksi perlu diperhitungkan, terutama di daerah yang mempunyai struktur tanah tidak stabil.

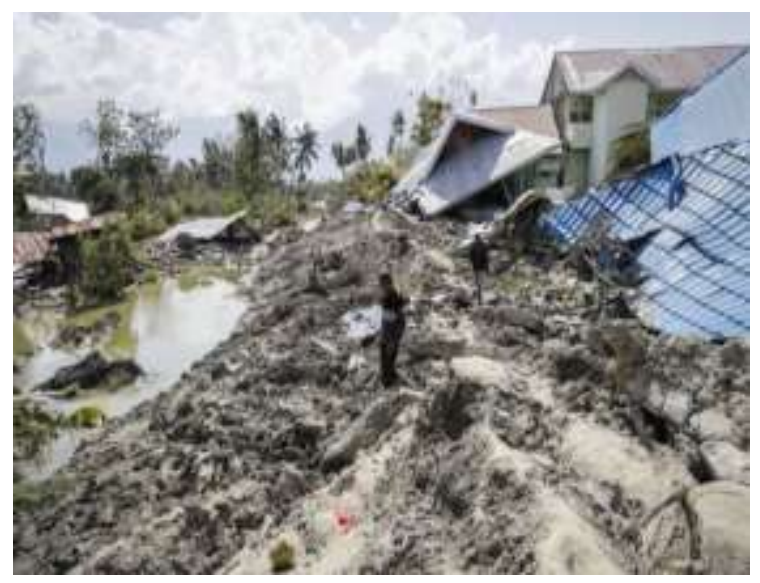

Gambar 2. Likuifaksi Palu 2018 (bbc.com)

Di samping peristiwa likuifaksi akibat gempa di Palu, gempa dan tsunami di Tohoku, Jepang (2011) juga memperlihatkan peristiwa scouring yang terjadi di sekitar fondasi dan mengakibatkan kerusakan yang serius pada bangunan (Gambar 3). Hal ini 
menjadi pertimbangan untuk tidak menggunakan fondasi dangkal di bangunan Temporary Evacuation Shelter (TES), untuk mencegah kegagalan struktur.

\section{Bangunan Temporary Evacuation Shelter}

Bappenas (2005) Temporary Evacuation Shelter harus memenuhi persyaratan terhadap (1) struktur (2) lantai evakuasi (3) fungsi (4) rancangan dan kapasitas (5) lokasi dan kemudahan akses (6) kemudahan akses vertikal (7) keamanan.

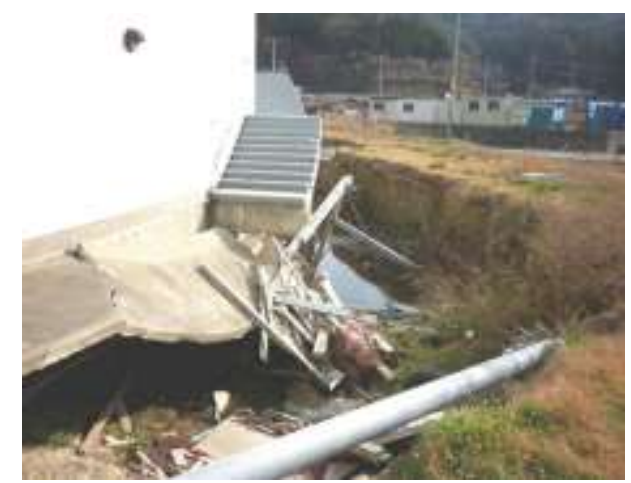

Gambar 3. Kerusakan fondasi akibat scouring (Satyarno, 2018)

Tempat perlindungan adalah sebuah fasilitas evakuasi yang dimaksudkan sebagai tempat yang aman terhadap bahaya yang terjadi, maupun terhadap potensi bahaya susulan. Dalam kasus tsunami, tempat penampungan sebaiknya mampu memenuhi kinerjanya selama beberapa jam setelah peristiwa tsunami sampai bahaya yang ditimbulkan oleh gelombang tsunami hilang. Hal ini dikarenakan pada kebanyakan wilayah, gelombang akan terjadi dalam 12 jam pertama setelah peristiwa memicu tsunami, kemudian potensi genangan air atau banjir yang sangat tinggi serta pasang surut air laut bisa bertahan selama 24 jam. Tempat penampungan diharapkan dirancang dan dibangun untuk memenuhi kriteria desain tsunami-resistant yang diperlukan sehingga dapat berfungsi dengan baik (FEM P646:2019).

\section{Perencanaan Temporary Evacuation Shelter}

Satyarno (2013) menyatakan bahwa banyaknya korban jiwa dapat dikarenakan:

1. Kurangnya edukasi tentang mitigasi.

2. Kurangnya sistem peringatan bencana.

3. Tidak adanya struktur penahan tsunami seperti seawalls dan juga struktur evakuasi vertical di daerah berpotensi tsunami

\section{Likuifaksi}

Soebowo dkk., (2009) menyebutkan bahwa gempa bumi dapat menimbulkan bahaya likuifaksi yang memberi dampak kerusakan pada bangunan dan sarana infrastruktur. Peristiwa likuifaksi pada lapisan tanah dipengaruhi oleh sifat keteknikan tanah, kondisi lingkungan geologi dan karakteristik gempa bumi. Beberapa faktor yang harus dipertimbangkan antara lain ukuran butir, muka air tanah dan percepatan getaran tanah maksimum (Seed dan Idriss, 1971).

\section{Scouring}

Tsunami di Tohoku, Jepang pada 2011 memberikan dampak kerusakan yang cukup parah pada bangunan di sekitar garis pantai (Gambar 3), di mana struktur fondasi di sekitar area tersebut mengalami keruntuhan. Hal ini diakibatkan oleh penggunaan fondasi dangkal (Satyarno, 2013). Sehingga penggunaan fondasi dangkal tidak disarankan pada perencanaan TES.

\section{Desain Fondasi Terhadap Beban Gempa}

Desain fondasi terhadap beban gempa dilakukan dengan memperhatikan syaratsyarat dan ketentuan desain dalam SNI 1726:2019 sebagaimana ditunjukkan dalam Pasal 7.13, desain fondasi harus memenuhi 
persyaratan terhadap beberapa hal sebagai berikut:

\section{(1) Dasar desain}

Fondasi harus didesain untuk menahan gaya yang dihasilkan dan mengakomodasi pergerakan yang disalurkan ke struktur oleh gerak tanah seismik desain.

Sistem fondasi tidak boleh gagal terlebih dahulu daripada struktur atas. Desain detail kekuatan struktur bawah harus memenuhi persyaratan beban gempa rencana berdasarkan kombinasi beban untuk metode ultimit pada Pasal 4.2.2.

\section{(2) Persyaratan struktur yang dirancang untuk kategori desain-desain seismik}

Persyaratan desain fondasi harus ditetapkan pada struktur yang dirancang untuk kategori desain seismik D, E, F dirujuk pada persyaratan tambahan laporan investigasi geoteknik untuk kategori desain seismik $D$ hingga $F$ pada Pasal 6.7.2. yang menjelaskan tentang potensi bahaya geologis dan seismik yang dapat terjadi termasuk bahaya likuifaksi.

Potensi likuifaksi dan kehilangan kekuatan tanah dievaluasi terhadap percepatan tanah puncak pada situs, magnitudo gempa, dan karakteristik sumber yang konsisten dengan percepatan puncak gempa maksimum yang dipertimbangkan.

Percepatan tanah puncak harus ditentukan dengan (1) kajian spesifik-situs dengan mempertimbangkan pengaruh amplifikasi yang secara spesifik, (2) percepatan tanah puncak PGAM, dari persamaan (15) sesuai dengan persyaratan tambahan laporan investigasi geoteknik untuk kategori desain seismik D hingga F pada Pasal 6.7.3.

\section{METODE}

Pada tahap ini dilakukan persiapan terhadap data dan pustaka sebagai sumber utama penelitian untuk mendapatkan parameter-parameter yang dibutuhkan dalam perhitungan potensi likuifaksi dan perhitungan desain tiang.

Data yang digunakan dalam penelitian ini meliputi :

- Data uji tanah (SPT)

- Data kelas situs tanah

- Data output beban struktur atas SAP2000

- Data spesifikasi tiang di lapangan

\section{Bangunan yang Ditinjau}

\section{(1) Lokasi}

Bangunan yang ditinjau adalah salah satu Temporary Evacuation Shelter (TES) di Indonesia (Gambar 4).
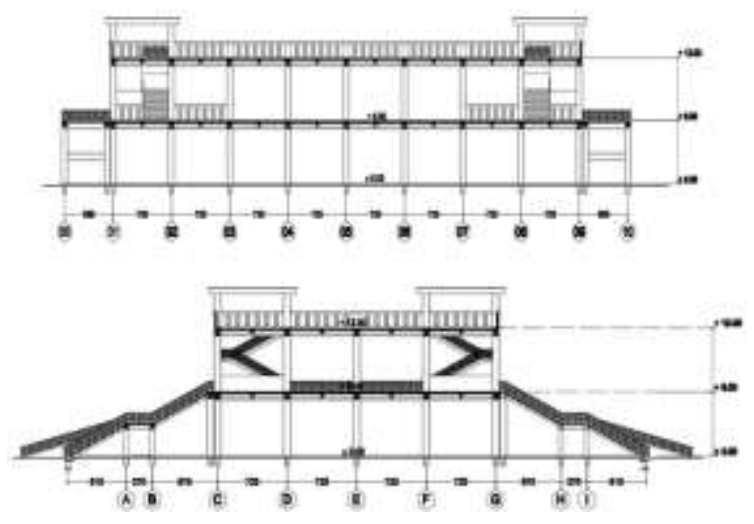

Gambar 4. Gambar rencana bangunan TES

\section{(2) Data Tanah}

Data tanah merupakan data sekunder yang diperoleh peneliti dari UPTD Balai Pengujian Konstruksi dan Lingkungan Sumatra Barat. Data diambil dari lokasi yang berdekatan dan memiliki struktur tanah yang sama.

\section{(3) Analisis Kekuatan Sistem Fondasi}

Analisis kekuatan sistem fondasi menggunakan software Plaxis 2D untuk 
mengetahui displacement dan momen yang terjadi pada tiang.

\section{(4) Analisis Kekuatan Tampang Fondasi}

Analisis kekuatan tampang menggunakan software Response 2000 dan SAP 2000 untuk mengetahui kapasitas tiang terhadap beban dan momen.

\section{(5) Data Beban Bangunan Atas}

Beban bangunan atas dan gempa diambil dari penelitian lain (Listyorini) berupa data output SAP 2000.

Analisis dilakukan dengan meninjau potensi likuifaksi terhadap fondasi yang terjadi di lokasi Temporary Evacuation Shelter (TES), kemudian dilanjutkan desain dan analisis kapasitas daya dukung tiang terhadap beban struktur atas TES yang direncanakan.

\section{(1) Analisa Potensi Likuifaksi}

Analisa potensi likuifaksi di lokasi TES dilakukan agar dapat meminimalisasi potensi terjadi keruntuhan di sekitar fondasi. Flowchart perhitungan analisa potensi likuifaksi dapat dilihat pada Gambar 5 . Perhitungan dilakukan dengan Metode Kuantitatif berupa konsep cyclic stress (Seed dan Idriss, 1971), dengan parameter

- Percepatan gempa maksimum (PGA)

- Cyclic Stress Ratio (CSR)

- Cyclic Retention Ratio (CRR)

- Indeks Potensi Likuifaksi (LPI)

Jalil (2020) telah mengkaji tentang potensi likuifaksi yang terjadi di Banda Aceh yang diakibatkan oleh gempa Aceh 26 Desember 2004 dengan Mw 9.2, menggunakan konsep perhitungan cyclic stress. Dari penelitian tersebut disimpulkan bahwa likuifaksi dengan potensi yang tinggi terjadi di sepanjang daerah pesisir Banda Aceh pada kedalaman 3-5 m dari permukaan.

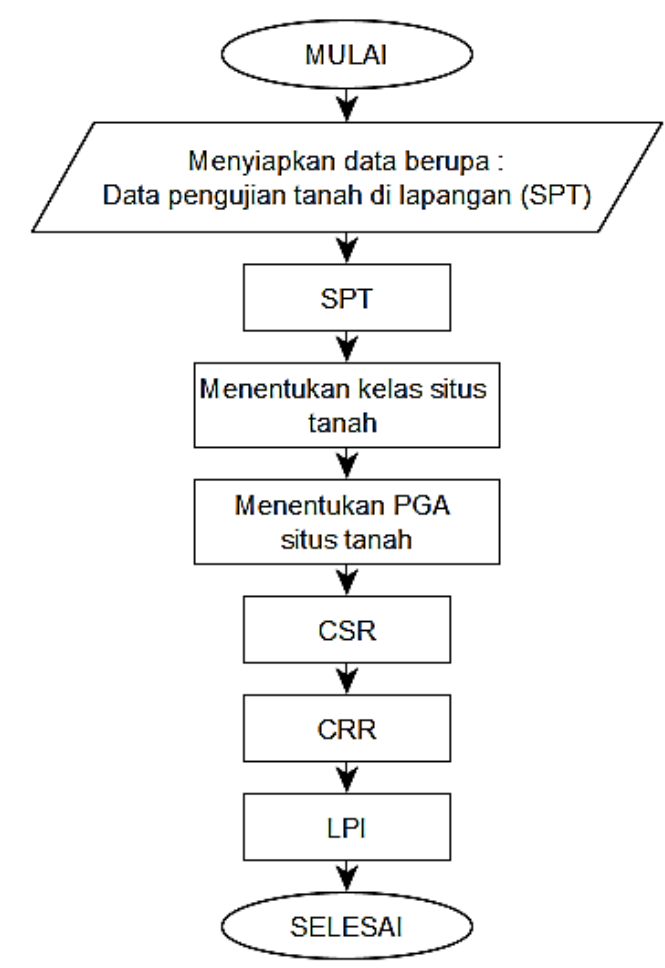

Gambar 5. Flowchart Analisa Potensi Likuifaksi

a. Menentukan kelas situs tanah

Nilai uji standard penetration test (SPT) rata-rata dibutuhkan untuk mengetahui karakteristik kelas situs tanah yang mempengaruhi faktor amplifikasi. Berdasarkan SNI 1726:2019, nilai SPT ratarata dapat dihitung dengan persamaan berikut:

$$
\bar{N}=\frac{\sum_{i=1}^{n} d_{i}}{\sum_{i=1}^{n} \frac{d_{i}}{N_{i}}}
$$

Di mana $d_{i}$ adalah ketebalan lapisan tanah i, (m), $\mathrm{N}_{\mathrm{i}}$ adalah nilai SPT lapisan tanah i yang ditinjau. Hasil nilai $\mathrm{N}$ rata-rata selanjutnya dirujuk pada Tabel 1 Nilai $\mathrm{N}$ rata-rata (SNI 1726:2019).

\section{b. Peak Ground Acceleration (PGA)}

Kelas situs tanah dan PGA situs diambil dari Desain Spektra Indonesia (puskim.pu.go.id). Percepatan Gempa Maksimum (PGA) adalah nilai yang diambil dari peta gerak seismik yang bersumber pada peraturan peta gempa Indonesia. 
Perancangan Fondasi Gedung... (Mitsaq/ hal 117-129)

Tabel 1. Kelas Situs

\begin{tabular}{cc}
\hline Nilai $\mathrm{N}$ rata-rata & Kelas situs \\
\hline $\mathrm{N} \geq 50$ & Tanah Keras $(\mathrm{SC})$ \\
15 sampai 50 & Tanah sedang \\
$\mathrm{N}<15$ & Tanah Lunak (SE) \\
\hline
\end{tabular}

Percepatan tanah puncak ditentukan dengan studi spesifik-situs dengan mempertimbangkan pengaruh amplifikasi yang secara spesifik, percepatan tanah puncak PGA adalah (SNI 1726:2019) :

$$
P G A_{M}=F_{P G A} \times P G A
$$

Di mana $P G A_{M}$ adalah percepatan tanah puncak yang disesuaikan dengan pengaruh klasifikasi situs, PGA adalah nilai diambil dari peta gerak seismik yang bersumber pada peraturan peta gempa Indonesia yang dapat diakses dari aplikasi Puskim, dan $F_{P G A}$ adalah faktor pengaruh klasifikasi situs kelas situs.

\section{c. Cyclic Stress Ratio (CSR)}

Cyclic Stress Ratio (CSR) adalah tegangan siklik gempa, untuk mengestimasi nilai induksi tegangan akibat gempa. Seed dan Idriss (1971) menjabarkan tegangan siklik gempa dengan persamaan berikut :

$$
C S R=0.65 \times\left(\frac{\sigma_{v c}}{\sigma_{v c}^{\prime}}\right) \times P G A_{M} \times r_{d}
$$

Di mana $\sigma^{\prime}{ }_{v c}$ adalah tegangan vertikal efektif dan $\sigma_{v c}$ tegangan total pada kedalaman $z$. Parameter $r_{d}$ adalah koefisien reduksi tegangan geser.

\section{d. Cyclic Resistant Ratio (CRR)}

Cyclic Resistance Ratio (CRR) adalah parameter ketahanan tanah untuk menahan beban siklik dari CSR. Nilai CRR menurut Idriss dan Boulanger (2004) dinyatakan sebagai berikut,

$C R R_{M, \sigma^{\prime} v c}=C R R_{M=7.5 \& \sigma^{\prime} v c=1} \times M S F \times K_{\sigma}(4)$

e. Liquefaction Potential Index (LPI)

Liquefaction Potensional Index (LPI) adalah indeks yang digunakan untuk mengetahui potensi suatu daerah terhadap risiko likuifaksi.

FSliq $=\frac{C R R}{C S R}$

Di mana $\mathrm{FS}_{\text {liq }}$ adalah faktor aman terhadap likuifaksi. Risiko potensi likuifaksi dapat diindikasikan sebagaimana pada Tabel 2 (Iwasaki, 1978):

Tabel 2. Liquefaction Potensional Index (LPI)

\begin{tabular}{cc}
\hline Liquefaction & Liquefaction risk \\
Potential Index (LPI) & Very Low \\
\hline $\mathrm{LPI}=0$ & Low \\
$0<\mathrm{LPI} \leq 5$ & High \\
$5<\mathrm{LPI}<15$ & Very High \\
$\mathrm{LPI}>15$ &
\end{tabular}

\section{(2)Perhitungan Desain Fondasi}

Untuk menghindari kerusakan yang sama akibat scouring, maka pemilihan fondasi yang tepat sangat diperlukan. Perhitungan dilakukan untuk mendapatkan hasil perancangan fondasi dalam untuk TES, berupa (1) panjang dan jenis tiang (2) diameter tiang (3) jumlah tiang (4) jarak antar tiang.

Sedangkan klasifikasi ditentukan berdasarkan beberapa poin diantaranya (1) jenis tanah sekitar lokasi TES (2) lokasi TES (3) jumlah lantai bangunan (4) potensi kerusakan sekitar lokasi TES dan (5) persyaratan pemilihan fondasi. Flowchart perhitungan desain fondasi dapat dilihat pada Gambar 6. Kapasitas ultimit tiang dapat dihitung secara empiris dari nilai $\mathrm{N}$ hasil uji SPT.

a. Kapasitas dukung ultimit $\left(Q_{u}\right)$

$Q u=Q b+Q s-W p$

b. Kapasitas dukung ijin $\left(Q_{a}\right)$

$$
Q a=\frac{Q u}{S F}
$$

c. Jumlah tiang pada 1 titik kolom

$$
n=\frac{Q}{Q a}
$$


Perancangan Fondasi Gedung... (Mitsaq/ hal 117-129)

Di mana, $\mathrm{W}_{\mathrm{P}}$ adalah berat sendiri tiang $(\mathrm{kN})$, $\mathrm{Q}_{\mathrm{u}}$ adalah kapasitas dukung ultimit neto $(\mathrm{kN}), \mathrm{Q}_{\mathrm{b}}=$ tahanan ujung bawah ultimit $(\mathrm{kN})$, dan $Q_{s}$ adalah tahanan gesek ultimit $(k N)$.

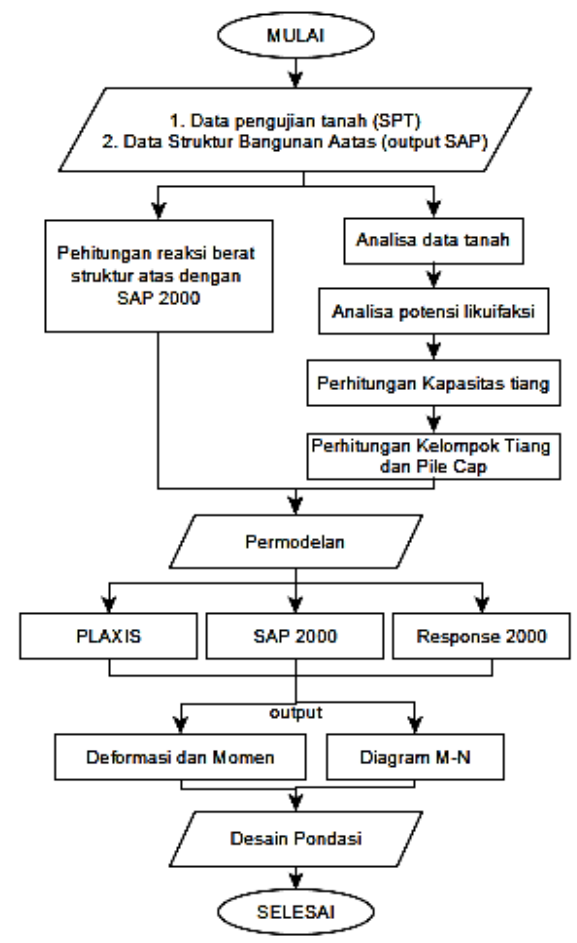

Gambar 6. Flowchart perhitungan desain fondasi

\section{(3) Persyaratan Pemilihan Fondasi}

Pemilihan fondasi selain ditinjau dari potensi terjadinya likuifaksi juga ditinjau dari persyaratan terhadap batas penurunan maksimum fondasi. Untuk tanah pasir, penurunan maksimum sebesar $40 \mathrm{~mm}$ dan nilai distorsi kaku $\delta / L$ sebesar $1 / 300$ (Hardiyatmo, 2002). Batas penurunan maksimum fondasi dan nilai distorsi kaku $\delta / L$ dapat dilihat pada Tabel 3 dan Tabel 4.

Tabel 3. Batas penurunan maksimum (Skempton dan McDonald, 1955)

\begin{tabular}{cc}
\hline Jenis Fondasi & $\begin{array}{c}\text { Batas Penurunan } \\
\text { Maksimum }(\mathrm{mm})\end{array}$ \\
\hline $\begin{array}{c}\text { Fondasi Terpisah } \\
\text { (isolated foundation) } \\
\text { pada tanah lempung } \\
\text { Fondasi terpisah } \\
\text { pada tanah pasir }\end{array}$ & 65 \\
\hline
\end{tabular}

\begin{tabular}{cc}
\hline Jenis Fondasi & $\begin{array}{c}\text { Batas Penurunan } \\
\text { Maksimum }(\mathrm{mm})\end{array}$ \\
\hline $\begin{array}{c}\text { Fondasi rakit pada } \\
\text { tanah lempung }\end{array}$ & $65-100$ \\
$\begin{array}{c}\text { Fondasi rakit pada } \\
\text { tanah rakit }\end{array}$ & $40-65$ \\
\hline
\end{tabular}

Tabel 4. Hubungan tipe masalah pada struktur dan ठ/L (Bjerrum, 1963)

\begin{tabular}{|c|c|}
\hline Tipe Masalah & $\delta / L$ \\
\hline $\begin{array}{l}\text { Kesulitan pada mesin yang sensitif } \\
\text { terhadap penurunan }\end{array}$ & $1 / 70$ \\
\hline $\begin{array}{l}\text { Bahaya pada rangka-rangka } \\
\text { dengan diagonal }\end{array}$ & $1 / 600$ \\
\hline $\begin{array}{l}\text { Nilai batas untuk bangunan yang } \\
\text { tidak diijinkan retak }\end{array}$ & $1 / 500$ \\
\hline $\begin{array}{l}\text { Nilai batas dengan retakan } \\
\text { pertama diharapkan terjadi pada } \\
\text { dinding-dinding panel, atau } \\
\text { dengan kesulitan terjadi pada } \\
\text { overhead crane }\end{array}$ & $1 / 300$ \\
\hline $\begin{array}{l}\text { Nilai batas dengan penggulingan } \\
\text { (miring bangunan tingkat tinggi } \\
\text { dapat terlihat }\end{array}$ & $1 / 250$ \\
\hline $\begin{array}{l}\text { Retakan signifikan dalam panel } \\
\text { dan tembok. } \\
\text { Batasan yang aman untuk dinding } \\
\text { tembok fleksibel dengan } \mathrm{h} / \mathrm{L}<1 / 4 \\
\text { ( } \mathrm{h}=\text { tinggi dinding) }\end{array}$ & $1 / 150$ \\
\hline
\end{tabular}

\section{HASIL DAN PEMBAHASAN}

Desain Fondasi terhadap SNI 1726:2019

Berdasarkan SNI 1726:2019 desain fondasi harus memenuhi persyaratan terhadap Pasal 7.13 meliputi beberapa hal :

\section{(1) Dasar desain}

Desain detail kekuatan bawah memenuhi persyaratan beban gempa rencana dengan kombinasi beban sesuai dengan Pasal 4.2.2 yaitu $1,2 \mathrm{D}+1,0 \mathrm{E}+\mathrm{L}$. 
(2) Persyaratan struktur yang dirancang untuk kategori desain desain seismik

Bangunan adalah bangunan evakuasi vertikal berupa Temporary Evacuation Shelter (TES) dikategorikan sebagai tempat perlindungan darurat dengan nilai SDS 0,932, sehingga memiliki kategori risiko IV, D. Berdasarkan Pasal 6.7.3, potensi likuifaksi dan kehilangan kekuatan tanah dievaluasi terhadap percepatan tanah puncak situs dengan nilai sebagai berikut. Nilai percepatan tanah puncak sebesar 0,515 sehingga didapat koefisien situs (FPGA) untuk tanah sedang (SD) adalah 1,0. Sehingga nilai PGAM didapat,

$P G A_{M}=F_{P G A} \times P G A=1 \times 0,515=0,515$

Selanjutnya parameter $\mathrm{PGA}_{M}$ digunakan dalam perhitungan likuifaksi sebagai percepatan maksimal.

\section{Analisa Desain Fondasi}

\section{(1) Analisa Potensi Likuifaksi}

Data N-SPT dari uji bore log kota Parupuk Padang (Gambar 7) menunjukkan tanah di sekitar lokasi berupa pasir-lanau nilai bervariasi antara rentang 4 hingga 55 dengan jenis tanah sedang (SD).

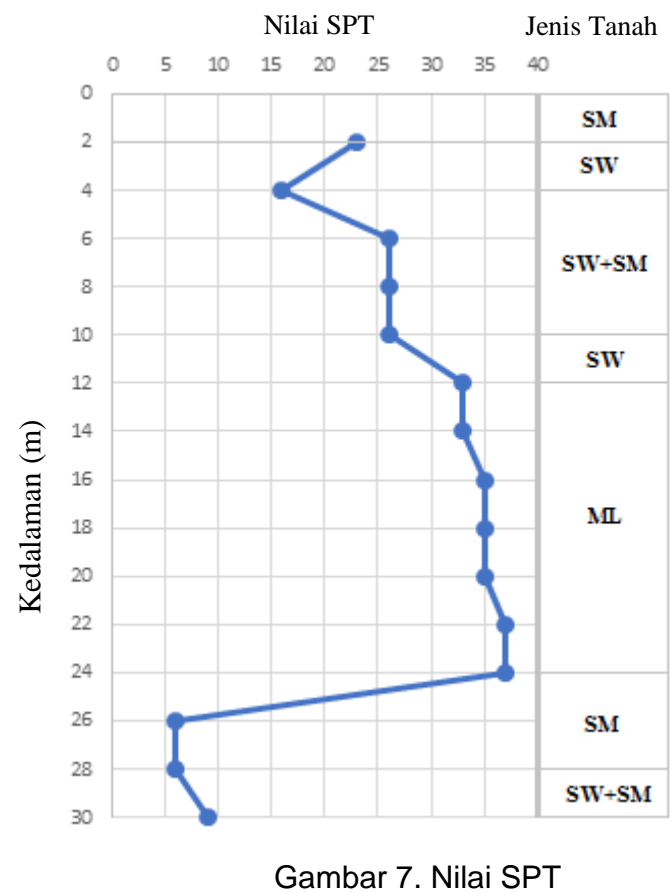

a. Momen magnitude gempa

Momen magnitude gempa berperan penting dalam analisa potensi likuifaksi yang merupakan beban siklik yang dialami tanah fondasi dan lereng. Penelitian ini menggunakan data dari Peta Gempa Indonesia 2016, dengan data Megathrust Middle 1 Sumatera, $\mathrm{Mw}=8.6$.

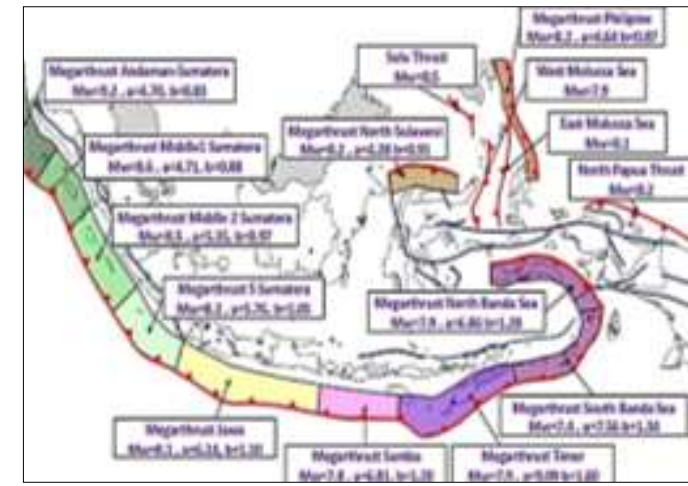

Gambar 8. Segmentasi Megathrust Peta Gempa Indonesia 2016

(Peta Gempa Indonesia 2015 dan 2016)

b. Cyclic Stress Ratio (CSR) dan Cyclic Resistant Ratio (CRR)

Dari olah data N-SPT dan parameterparameter pendukung lain, didapat nilai CSR dan CRR. Grafik hubungan nilai CSR dan CRR berdasarkan perhitungan dapat dilihat pada Gambar 8. Apabila nilai CRR<CSR dapat disimpulkan bahwa tanah mengalami likuifaksi.

CRR \& CSR

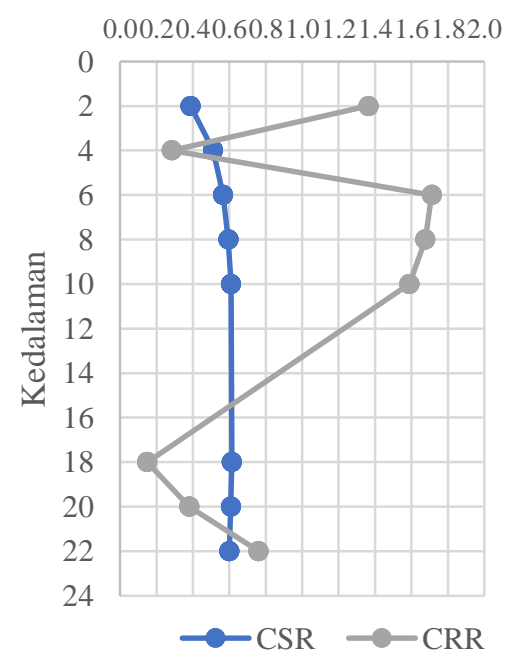

Gambar 9. Hubungan nilai CSR dan CSR 
c. Liquefaction Potential Index (LPI)

Liquefaction Potensional Index (LPI) menjelaskan potensi likuifaksi yang terjadi pada tanah. Safety factor likuifaksi (FS Liq) $<1$ menunjukkan terjadinya likuifaksi, sedangkan (FS Liq)>1 menunjukkan lokasi aman dari potensi terjadinya likuifaksi.

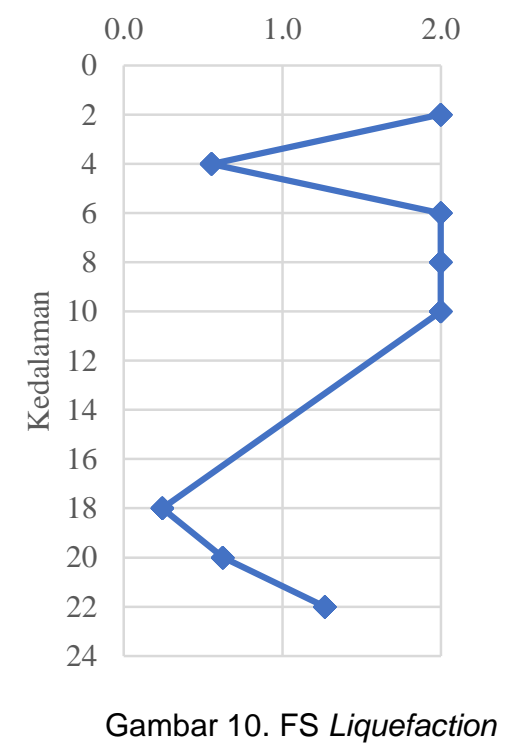

Berdasarkan perhitungan hubungan CSR dan CSR serta Indeks Potensi Likuifaksi (LPI), diketahui likuifaksi terjadi di kedalaman $4 \mathrm{~m}$.

\section{(2) Perhitungan Desain Fondasi}

Perhitungan desain fondasi didasarkan pada beban bangunan dari perhitungan struktur atas. Kombinasi beban yang digunakan sesuai SNI 1726:2019 dengan kombinasi pada pasal 4.2.2 dan momen yang terjadi pada joint dengan beban terbesar (Lampiran 1).

Tiang dianalisa dengan beberapa variasi diameter untuk mengetahui kedalaman yang paling aman dan memenuhi kapasitas. Diameter yang digunakan disesuaikan dengan produk spun pile yang tersedia di lapangan. Dalam analisa ini digunakan produk pre-tensioned spun concrete Tekcon Technologies, WIKA Clt Standard, dengan spesifikasi seperti di Tabel 5.
Tabel 5. Pre-tensioned Spun Concrete Spesification (Tekcon Technologies, WIKA Clt Standard)

\begin{tabular}{cc}
\hline $\begin{array}{c}\text { Outer } \\
\text { Diameter }(\mathrm{mm})\end{array}$ & $\begin{array}{c}\text { Concrete Wall } \\
\text { Thickness }(\mathrm{mm})\end{array}$ \\
\hline 300 & 60 \\
350 & 70 \\
400 & 75 \\
450 & 80 \\
500 & 90 \\
600 & 100 \\
\hline
\end{tabular}

a. Perhitungan kapasitas tiang tunggal Berdasarkan Gambar 9 dan 10, likuifaksi terjadi pada kedalaman $4 \mathrm{~m}$, sehingga kedalaman tiang minimal yang digunakan pada perhitungan kapasitas tiang adalah 5,5 m. Hasil berupa kapasitas dukung ultimit terhadap tahanan aksial tiang $\left(Q_{u}\right)$, kapasitas dukung izin terhadap tahanan aksial tiang $\left(\mathrm{Q}_{\mathrm{a}}\right)$, tahanan lateral tiang $\left(\mathrm{H}_{\mathrm{a}}\right)$ digunakan sebagai variabel pada perhitungan kapasitas kelompok tiang dan pile cap. Dengan kedalaman dan beban yang digunakan dapat dilihat pada Tabel 6 .

Tabel 6. Hasil Perhitungan Kapasitas Tiang

\begin{tabular}{ccccc}
\hline $\begin{array}{c}\mathrm{D} \\
(\mathrm{m})\end{array}$ & $\begin{array}{c}\mathrm{h} \\
(\mathrm{m})\end{array}$ & $\begin{array}{c}\mathrm{Q}_{\mathrm{u}} \\
(\mathrm{kN})\end{array}$ & $\begin{array}{c}\mathrm{Q}_{\mathrm{a}} \\
(\mathrm{kN})\end{array}$ & $\begin{array}{c}\mathrm{H}_{\mathrm{a}} \\
(\mathrm{kN})\end{array}$ \\
\hline 0.3 & 9.50 & 1338.73 & 535.49 & 38.61 \\
0.35 & 8.50 & 1623.53 & 649.41 & 59.95 \\
0.4 & 8.5 & 1977.06 & 790.82 & 82.60 \\
0.45 & 8.5 & 2437.25 & 974.90 & 109.59 \\
0.5 & 6.5 & 2484.35 & 993.74 & 136.69 \\
0.6 & 6.5 & 3362.17 & 1344.87 & 211.73 \\
\hline
\end{tabular}

b. Perhitungan kapasitas kelompok tiang dan pile cap

Dari perhitungan kelompok tiang, didapat beberapa variasi jumlah tiang dan kedalaman yang memenuhi kapasitas, seperti yang ditunjukkan pada Tabel 7 berikut. 
Perancangan Fondasi Gedung... (Mitsaq/ hal 117-129)

Tabel 7. Hasil perhitungan kelompok tiang dan pile

\begin{tabular}{|c|c|c|c|c|}
\hline & & cap & & \\
\hline Diam & er (m) & Tebal pile & $\mathrm{H}$ tiang & Jumlah \\
\hline Outer & Inner & cap (m) & $(\mathrm{m})$ & tiang \\
\hline 0.3 & 0.18 & 0.06 & 9.50 & 8 \\
\hline 0.35 & 0.21 & 0.07 & 8.50 & 7 \\
\hline 0.4 & 0.25 & 0.075 & 8.50 & 5 \\
\hline 0.45 & 0.29 & 0.08 & 8.50 & 4 \\
\hline 0.5 & 0.32 & 0.09 & 6.50 & 4 \\
\hline 0.6 & 0.4 & 0.1 & 6.50 & 3 \\
\hline
\end{tabular}

\section{(3) Permodelan}

Permodelan dilakukan dengan menggunakan 3 software: (1) Plaxis 2D (2) SAP2000 (3) Response 2000. Masingmasing pemodelan menggunakan variasi diameter tiang sesuai Tabel 5. Permodelan bertujuan untuk mengetahui kapasitas masing-masing diameter tiang, yang selanjutnya akan diplot ke dalam diagram interaksi M-N.

Permodelan ditampilkan dengan dimensi dan kedalaman yang digunakan sebagai desain final. Untuk output dan hasil permodelan secara lengkap dapat dilihat pada lampiran.

\section{a. Plaxis 2D}

Permodelan Plaxis 2D dengan memasukkan variabel berupa spesifikasi tiang (Tabel 5), material tanah, dan material tiang menggunakan Axissymmetry model.

Tiang dan pile cap dimodelkan dengan input beban yang bekerja pada tiang berupa point load seperti pada Gambar 11. Beban berdasarkan kombinasi beban F3 (Np) dan F1 (Vp) terbesar dari hasil output SAP 2000 (Lampiran 1) dibagi dengan jumlah tiang yang digunakan (Tabel 8).

\begin{tabular}{cccc}
\multicolumn{4}{c}{ Tabel 8. Beban Np dan Vp } \\
\hline \multirow{2}{*}{ Diameter } & $\begin{array}{c}\text { Jumlah } \\
\text { tiang }\end{array}$ & $\mathrm{Np}(\mathrm{y})$ & $\mathrm{Vp}(\mathrm{x})$ \\
\hline 300 & 8 & 302.7846 & 12.2385 \\
350 & 7 & 346.0396 & 13.98686 \\
400 & 5 & 484.4554 & 19.5816 \\
\hline
\end{tabular}

\begin{tabular}{|c|c|c|c|}
\hline \multirow{2}{*}{ Diameter } & \multirow{2}{*}{$\begin{array}{c}\text { Jumlah } \\
\text { tiang }\end{array}$} & \multicolumn{2}{|c|}{$P$} \\
\hline & & $\mathrm{Np}(\mathrm{y})$ & $V p(x)$ \\
\hline 450 & 4 & 605.5693 & 24.477 \\
\hline 500 & 4 & 605.5693 & 24.477 \\
\hline 600 & 3 & 807.4257 & 32.636 \\
\hline
\end{tabular}

Output permodelan yang dihasilkan berupa deformasi (Gambar 12) dan momen (Gambar 13) yang terjadi pada tiang di tiap variasi diameter dan kedalaman dapat dilihat pada Tabel 9.

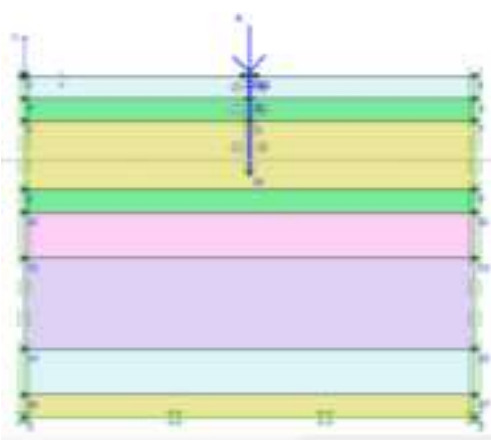

Gambar 11. Input Permodelan Plaxis 2D

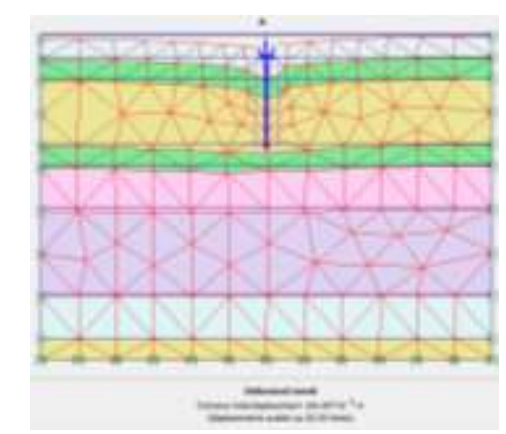

Gambar 12. Output Permodelan Plaxis berupa deformasi yang terjadi pada tiang.

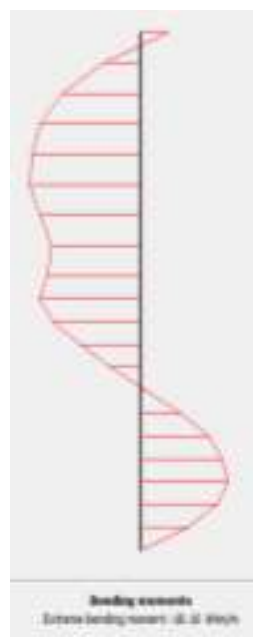

Gambar 13. Output Permodelan Plaxis, berupa bending moments yang terjadi pada tiang. 
Tabel 9. Displacement dan Momen

\begin{tabular}{ccc}
\hline $\mathrm{D}$ & $\begin{array}{c}\text { Displacement } \\
(\mathrm{cm})\end{array}$ & $\begin{array}{c}\text { Momen } \\
(\mathrm{kNm} / \mathrm{m})\end{array}$ \\
\hline 300 & 1.903 & -5.62 \\
350 & 2.23 & -7.26 \\
400 & 5.932 & -16.56 \\
450 & 7.687 & -19.95 \\
500 & 8.105 & -21.08 \\
600 & 12.152 & -13.38 \\
\hline
\end{tabular}

b. SAP 2000

Permodelan awal dilakukan dengan memodelkan tiang beserta beban yang terjadi (Gambar 14). Variabel berupa diameter tiang (Tabel 5), tulangan, dan jarak tulangan serta beberapa variabel lain, kemudian dianalisa dengan section designer SAP 2000, sehingga didapat model seperti pada Gambar 15.
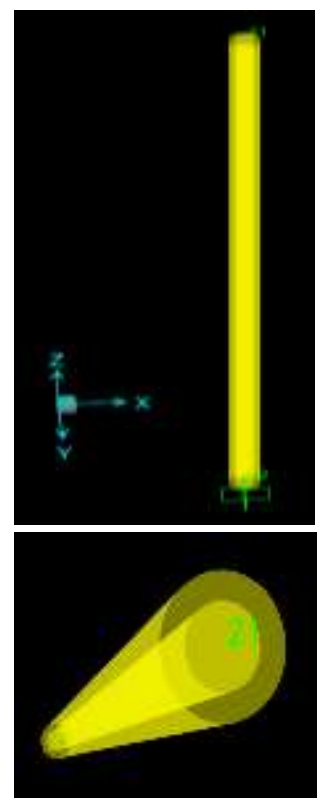

Gambar 14. Permodelan tiang SAP 2000

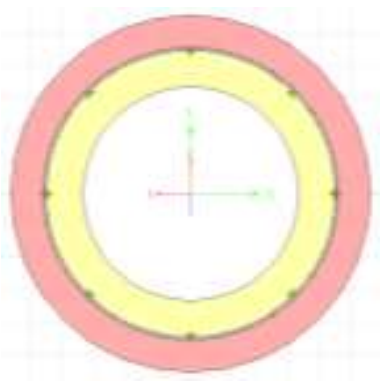

Gambar 15. Section designer SAP 2000
Output model yang didapat berupa moment cuvature yang terjadi pada tiang (Gambar 16).
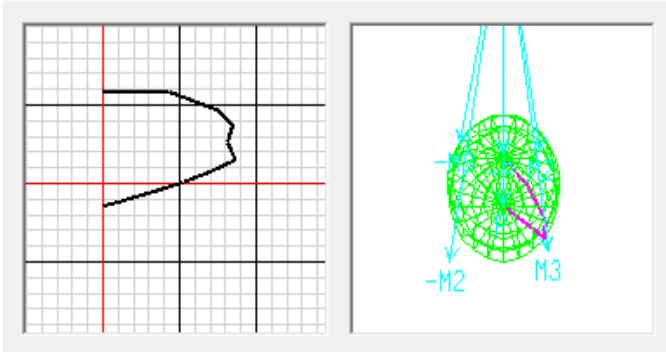

Gambar 16. Moment Curvature

C. Response 2000

Permodelan Response 2000 dengan memasukkan variabel berupa spesifikasi tiang (Tabel 5), tebal selimut, tulangan, dan jarak tulangan serta beberapa variabel lain, sehingga didapat model seperti Gambar 17.

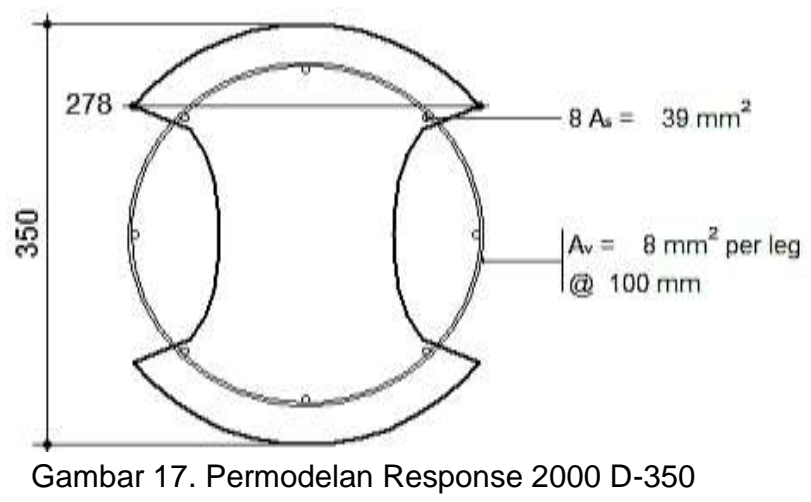

Output model yang didapat berupa Diagram $M-N$ Interaction yang terjadi pada tiang.

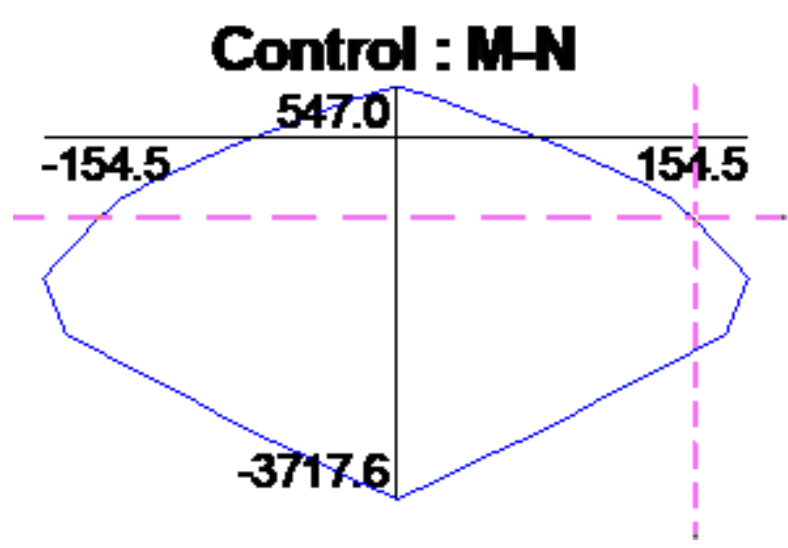

Gambar 18. Output Permodelan Response 2000 D350 
Perancangan Fondasi Gedung... (Mitsaq/ hal 117-129)

\section{d. Diagram Interaksi M-N}

Dari permodelan Plaxis 2D, SAP 2000, dan Response 2000 didapat hasil output berupa momen dan deformasi yang terjadi pada tiang. Momen dan deformasi per tiang dari permodelan Plaxis 2D yang terjadi kemudian diplot ke dalam diagram interaksi M-N yang didapat dari SAP 2000 dan Response 2000. Beban dan momen yang terjadi pada masing-masing variabel tiang hasil output Plaxis 2D dapat dilihat pada Tabel 10.

\begin{tabular}{ccc}
\multicolumn{3}{c}{ Tabel 10. Beban dan Momen output Plaxis 2D } \\
\hline $\mathrm{D}(\mathrm{mm})$ & $\mathrm{N}(\mathrm{kN})$ & $\mathrm{M}(\mathrm{kNm})$ \\
\hline 300 & -302.78 & -5.62 \\
350 & -346.04 & -7.26 \\
400 & -484.46 & -16.56 \\
450 & -605.57 & -19.95 \\
500 & -605.57 & -21.08 \\
600 & -807.43 & -13.38 \\
\hline
\end{tabular}

Hasil Plot deformasi dan momen terhadap diagram $\mathrm{M}-\mathrm{N}$ adalah sebagai berikut (Gambar 19). Tanda (•) berada di dalam area grafik menunjukkan bahwa pile dengan diameter dan spesifikasi di bawah aman untuk kontruksi.

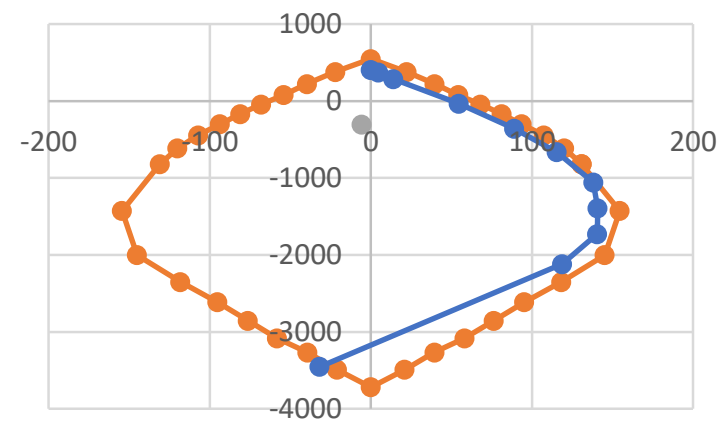

Gambar 19. Plot deformasi dan momen terhadap diagram $\mathrm{M}-\mathrm{N}$.

\section{SIMPULAN}

Dari hasil analisis tinjauan potensi likuifaksi yang terjadi, disimpulkan bahwa likuifaksi terjadi pada kedalaman tanah $4 \mathrm{~m}$ dari permukaan. Hal ini diidentifikasikan dari hubungan CRR dan CRR serta LPI terhadap kedalaman. Dimana pada kedalaman tersebut $\mathrm{CRR}<\mathrm{CSR}$ dan $\mathrm{FS}_{\text {liq }}<1$.

Output diagram M-N memperlihatkan bahwa semua variasi diameter dan kedalaman memenuhi kapasitas terhadap beban yang terjadi pada kolom dari SAP 2000.

Hardiyatmo (2002) menerangkan bahwa displacement tiang maksimal yang terjadi pada tanah pasir adalah $4 \mathrm{~cm}$, sehingga perancangan fondasi dipilih pada diameter dan kedalaman yang memiliki displacement kurang dari $4 \mathrm{~cm}$ dan memiliki dan nilai distorsi kaku $\delta / L$ sebesar 1/300. Nilai distorsi kaku yang terjadi dapat dilihat pada Tabel 11.

\begin{tabular}{ccc}
\multicolumn{3}{c}{ Tabel 11. Nilai Distorsi Kaku } \\
\hline $\begin{array}{c}\mathrm{D} \\
(\mathrm{mm})\end{array}$ & $\delta / \mathrm{L}$ & Keterangan \\
\hline 300 & 0.002643 & OK \\
350 & 0.003097 & OK \\
400 & 0.008239 & NOT OK \\
450 & 0.010676 & NOT OK \\
500 & 0.011257 & NOT OK \\
600 & 0.016878 & NOT OK \\
\hline
\end{tabular}

Sehingga dapat disimpulkan bahwa untuk desain fondasi dipilih tiang spun berdiameter $350 \mathrm{~mm}$ dan jumlah tiang 7 buah dengan displacement 2,23 cm (Tabel 9) dan nilai distorsi kaku sebesar 0,003097 (Tabel 11).

\section{DAFTAR RUJUKAN}

Abdurrosyid, Jaji., Fatchan, Karim. (2007). Scour Around Abutment and Its Countermeasure In Live Bed Scour Condition on Compound Channel.

Das, Braja. (2007). Principles of Foundation Engineering.

Das, M.Braja. Principles of Foundation Engineering Eight Edition. (2014). United States America. Cengange Learning. 
Hardiyatmo, Hary Christady. (2002). Mekanika Tanah I. Yogyakarta. Gadjah Mada University Press.

Hardiyatmo, Hary Christady. (2003). Mekanika Tanah II. Yogyakarta. Gadjah Mada University Press.

Hardiyatmo, Hary Christady. (2008). Teknik Fondasi II Edisi ke-4. Yogyakarta. Gadjah Mada University Press.

Hardiyatmo, Hary Christady. (2010). Analisis \& Perancangan Fondasi Bagian II. Yogyakarta. Gadjah Mada University Press.

Hardiyatmo, Hary Christady. (2011). Analisis \& Perancangan Fondasi Bagian I Edisi ke-2. Yogyakarta. Gadjah Mada University Press.

Idriss, I.,Boulanger, R. (2008). Soil Liquefaction During Earthquakes.

Iwasaki, Toshio. (1981). Soil Liquefaction Potential Evaluation with Use of the Simplified Procedure.

Iwasaki, Toshio. (1984). Simplified procedures for assessing soil liquefaction during earthquakes.

Iwasaki, Toship. (1986). Soil liquefaction studies in Japan: state-of-the-art.

Jayaratne, Mantripathi., Premaratne, Buddhika., Adewale, Abimbola. (2016). Failure Mechanisms and Local Scour at Coastal Structures Induced by Tsunami.

Mase, Lindung. (2018). Studi Kehandalan Metode Analisis Likuifaksi Menggunakan SPT Akibat Gempa 8,6 Mw, 12 September 2007 di Area Pesisir Kota Bengkulu.

Okamoto, Osamu., Oda, Katsuya., Kumagai, Kentaro. (2008). Study On Scour By Tsunamis-Examples Of Port And Harbor Structures-.

Pratama, G. N. I. P. P., \& Najihan, H. F. (2020, September). The Effect of Beach Sands to Replacement of Fine Aggregate with Addition Filler of Ash Cane on the Asphalt Mixture on Marshall Characteristics.
In Journal of Physics: Conference Series (Vol. 1625, No. 1, p. 012032). IOP Publishing.

Putra, Hendri., Hakam, Abdul., Lastaruna Dody. (2009). Analisa Potensi Likuifaksi Berdasarkan Data Pengujian Sondir (Studi Kasus Gor Haji Agus Salim Dan Lapai, Padang)

Ryltenius, Andre. (2011). FEM Modelling of Piled Raft Foundations in Two and Three Dimensions. Carolina. Department of Construction Sciences Geotechnical Engineering.

Satyarno, I. (2013). Assessment of the 2004/2011 Earthquakes and Tsunamis in Indonesia and Japan: Lesson Learnt and Way Forward.

Satyarno, I.,dkk. (2018). Laporan Kegiatan Partisipasi Stirrrd Ugm Dan Fakultas Teknik Ugm Dalam Penanganan Bencana Gempa Bumi Lombok.

Youd, T., Idriss, I. (2001). Liquefaction Resistance Of Soils: Summary Report From The 1996 Nceer And 1998 Nceer/Nsf Workshop On Evaluation Of Liquefaction Resistance Of Soils 